\title{
The Efforts of Civic Education Teachers in Strengthening Students' Civic Disposition
}

\author{
Sjamsi Pasandaran, Apeles Lexi Lonto, Theodorus Pangalila, and Rebbi Alimbalu Barahama \\ Universitas Negeri Manado \\ Manado, Indonesia \\ spasandaran@unima.ac.id
}

\begin{abstract}
The core issues presented in this research stem from the actual Civic Education learning process which emphasizes more on the process of knowledge transfer than the process of strengthening and character building particularly students' civic disposition. The purpose of this research is to elaborate the efforts which have been done by the teachers in developing and strengthening Civic Disposition of the students in State Senior High School 1 Lobbo. The underlying theory used in the research is the notion that civic disposition is one of the important elements in civic education, and teachers have a significant role in the process of civic disposition strengthening through Civic learning at school. This research conducted by using the descriptive qualitative method and data collected from the interview, observation, and documentation. The result of the research underlines some important characteristics in the effort to strengthen student's civic disposition, such as the importance of different implementation of value-based learning model, diversity of implementation of value-based learning model, strengthening core values building, and strengthening the function of teachers as the role models through the dialogical and interactive process. Various implementation of value-based learning model can be done by reinforcing core values as preferences for both individuals and schools by providing interactive and dialogical learning experiences between students and students, students with teachers, and students with their environment. This study recommended that teachers strengthen in developing value-based learning models through practical activities in and out of the classroom.
\end{abstract}

Keywords- civic disposition; value-based teaching and learning process; core values

\section{INTRODUCTION}

Research on the efforts of Civic Education teachers in building students' civic disposition in schools is carried out due to several considerations. First, the weakness of education praxis in building character pillars. Character learning process is more directed to the development of cognitive ability through the transfer of knowledge process, so this process does not provide more learning experiences which encourage the process of character building (loving the good) and ability to do the good. Second, the establishment of civic disposition is an essential part of the demands in global citizenship formation. Civic disposition does not only contain local and national values but also the values needed in the life of a global community. In the era of globalization and information and communication technology advance, students need to be prepared to live and interact in a global community. Third, Indonesia is a pluralistic society due to religion, language, ethnicity, tradition, and culture. There is a reality which poses a threat to the life of society, nation and state as the weakness of recognition of cultural diversity, intolerance, violence and harassment, hoax and more increasingly widespread hate speech phenomenon. The root of any problems that occur in Indonesia if traced it has a close relationship with the character or evil character of Indonesian man. The deterioration in the quality of human resources in Indonesia can be seen, among others, on the Human Development Index data for three consecutive years $(2009,2010,2011)$ [1].

This research particularly examines the efforts which have been done by civic education teachers in shaping civic disposition such as to identify learning characteristics and students' learning experiences which the teachers have developed. Teachers do not only teach but also are responsible for shaping the great attitude of their students (by providing multicultural-based Civics learning). In the learning process, teachers of Civics have to involve other resources such as society living near the school, government buildings, churches, cultural sites and others [2].

\section{THEORETICAL}

Civic disposition deals with issues of attitudes, characters, and values which become motivational preferences and strength for individual or social behaviors. Whether someone decides to do or not to do something depends on her/his value preference. Everyone has different civic disposition depending on his/her value configuration. For students to be prepared for participation in a democracy, such socialization must include an educational experience that promotes analytical thinking, open discussion, and respectful debate [3]. Civic disposition characterizes a person's self-quality especially the character and moral qualities. Civic disposition serves as the foundation and basis for judging whether someone has good moral or bad moral, has good and evil characters, and becomes a good or bad citizen. Diane Owen defines civic disposition as a concern for others' rights and welfare, fairness, reasonable levels of trust, and a sense of public [4]. The definition of civic disposition refers to the character traits such as awareness and concern of others' right, welfare, fair and objective treatment, trustworthiness, and sensitivity to living together. Concern and attention will result in attitude and respectful character which 
Diane calls as respect such as respect for the rule of law, respect for human rights, concern for the welfare of others, civility, social responsibility, and community connectedness [4]. Critical pedagogies build on the critical project of reconceptualizing how youth express their awareness of what gives rise to salient social issues, such as racism, violence, environmental degradation, poverty, gender inequalities, and how they work actively with other citizens to extend social and political rights for all citizen [5].

The development and building of civic disposition are one of the essential elements in Civic Education besides civic knowledge and civic skills. The analysis of the school curriculum including the high school curriculum shows that civic disposition building contains following aspects (1) the religious referring to religious life, (2) honesty, (3) discipline, (4) responsibility, (5) politeness, (6) caring, tolerance, and peacefulness, (7) confidence, (8) effective interaction with the environment, (9) participation in solving problem together, (10) responsive and proactive [6]. A review of some literature results in three main components of Civic Education: civic knowledge, civic skills and civic disposition [7]. Civic disposition has a function to build character such as common attitudes and character, honest, responsible, caring for common interests, respect for human rights. Civic disposition will be very helpful to someone regarding care, attention, and empathy, so students can interact and communicate positively and productively for the sake of rights and obligations as citizens and the benefit of living in the community, nation, and state.

According to Budimansyah and Suryadi in the constellation of Indonesian national education, Citizenship Education (Civics) is one of the studies which undertakes a national mission to educate Indonesians through the corridor of "valuebased education." Configuration or systematic framework of Civics is formulated based on the following paradigm: First, Civic curriculum designed as a learning subject that aims at developing the potential of individuals to become citizens of Indonesia with a noble character, intelligence, participative role, and responsibility. Second, Civic Education theoretically designed as a learning subject which contains cognitive, affective, and psychomotor dimensions. These dimensions are confluent or mutually penetrated and integrated into the substance of Pancasila ideas, values, concepts and morals, democratic citizenship, and state defense. Third, Civic Education programmatically designed as a learning subject which emphasizes content-embedding values and learning experience in behaviors of everyday life. It serves as the fundamental of life for all citizens in social life, nation, and state as the further explanation of Pancasila ideas, values, concepts and morals, democratic citizenship and state defense [8].

Therefore, teachers have significant roles in building civic disposition. First, a teacher is the model. Teachers become the role models for their students in knowledge, attitude, and behavior. Research conducted by Lumpkin found that $62 \%$ of students imitate significant attitudes and behavior of teachers [9]. Lunenburg, Korthagen, and Swennen suggest that the teacher's role is seen explicitly or implicitly through utterance which must reflect in attitudes and behavior. Second, teachers become the leaders. The teacher leadership becomes a significant factor in building civic disposition [10]. The result of research of Nassozi shows that teacher leadership has a significant impact on building disciplines in students. The three academic roles of teachers are mainly related to teachers' competence in both pedagogic and professional competences. Teachers must have mastery of pedagogic principles, subject matter or teaching materials [11]. Global citizenship education, or education aiming to develop teacher candidates' knowledge and empathy with transnational challenges, has become increasingly recognized as an important field internationally, requiring a particular set of pedagogical understandings and tools to facilitate learning [12].

\section{METHOD}

This research conducted in State Senior High School 1 Lobbo Regency of Sangihe Islands. The research was conducted using the qualitative descriptive method. The research involved teachers as the subjects, and data collected from observation, interview, and documentation. Then, data processed by using interactive analysis model starting from data collection, data reduction to the conclusion.

\section{RESUlt AND DiscusSION}

The data analysis results in some important characteristics in the efforts having been done by Civic Education teachers to build students' civic disposition. Teachers have conducted various efforts to develop civic disposition by building attitude which shows students' devotion to God. Teachers ask the students to pray before and after the class. Teachers also encourage students to perform their religious duties according to their belief, to help each other, and show their concern to their sick friends. Teachers also foster and build students' friendly attitude and behavior by encouraging the students to use polite language, speak in a good manner to parents, teachers, older people and friends, and not to use rude language or abusive words. Teachers also foster students' discipline by asking them to come to class on time, finish all school assignment, maintain a peaceful atmosphere inside and outside the class, and obey school regulations. A sense of responsibility built by giving them responsibility for certain activities. Teachers also foster students' honesty in accomplishing assignment and taking the tests.

This research also points out several relevant facts: First, Civic Education learning in which the teachers foster the process of a civic disposition not merely restricted on the transfer of knowledge process. In the last decades, Civic Education (CE) has been at the forefront of both educational policies and international research regarding curriculum design and impacted on pupils' knowledge, values, and skills [12]. Teachers have made various efforts to develop learning by providing practical experiences in which students learn some activities as a habituation process. Civic disposition built through the habituation process which embedded in various students' activities inside and outside the classroom. Second, Various efforts which Civic Education teachers at State Senior High School 1 Lobbo have made in establishing civic disposition strengthen and expand civic disposition aspects. Those efforts have strengthened the meaning of civic 
disposition as the superior attitude, character, and values which focus on the establishment of values of piety, politeness and courtesy, disciplines, responsibility, and honesty. Various efforts and civic disposition aspects reinforce Diane Owen's thesis about the essence and meaning of civic disposition which focuses on the attitude and character of respect towards others. Various efforts to establish civic disposition having been done by the teachers reinforce aspects of civic disposition within the school curriculum such as religiosity or pluralism, honesty, discipline, responsibility, courtesy and politeness [6]. Further, these efforts strengthen the thesis from Margaret Stimman Branson and Charles Quigley. In the constellation of national education, the efforts of these teachers strengthen the Civic Education mission to capture the nation's life and character formation of the nation [8].

The research findings indicate that teachers have significant roles in the formation of civic disposition. Teachers do not only perform the transfers of knowledge but also play a role as a model. This finding supports the results of research which argues that the attributes of teachers' characters have a significant impact on the formation of civic disposition $[9,11]$. Teachers must have three important characteristics to be role models; those are academic characteristic, leadership characteristic, and good characteristic. Academic characteristic underlines that teachers' ability to develop various learning activities such as approaches, method, and value-based learning is undeniably crucial to building civic disposition. Implementation of these models can be done through habituation process in various activities of students inside and outside the classroom. The formation of civic disposition can be done through the practical activities which students regularly perform every day. Thus the effort to foster the civic disposition should always involve students, and the teachers have the task to develop learning activities or learning experiences to encourage students' active participation in every activity aiming at building their civic disposition. The learning process can be designed and designed by providing learning experiences which enable students to be active in meaningful activities for the formation of students' attitudes and characters.

Civic disposition cannot shape through lectures, so teachers must provide experiences through which the students get accustomed to self-learning. The sense of discipline, honesty, responsibility, caring, and fairness will be formed through the habituation process through activities inside and outside the classroom. This process requires leadership character as a model. Teachers must act as leaders whose functions are to provide encouragement, motivation, and inspiration for students. The teacher's moral attitudes and behavior will serve as the moral and ethical ground for students when they face adversities in choosing various values in life. Attitudes and moral behavior of teachers must inspire students to determine the choice of values; in other words, teachers' attitudes and behavior can be the examples for the students.

\section{CONCLUSION}

Based on the results of research and discussion, some concluding remarks can be taken as follows: (1) Teachers of Civic Education in State Senior High School 1 Lobbo have conducted many efforts to build students' Civic Disposition. (2) The learning process of building civic disposition will be effective if it is developed through the practical activities of students every day inside and outside the classroom. (3) The effectiveness of civic disposition characterized by teacher characteristics as a model, leadership characteristics, and teachers' academic characteristics. This research recommended that teachers' ability strengthening be necessary to develop value-based learning models through practical activities in and out of the classroom

\section{ACKNOWLEDGMENTS}

The author would like to say thank Dean of Social Science Faculty Manado State University.

\section{REFERENCES}

[1] Lonto, A. L. (2015). Pengembangan model pendidikan karakter berbasis nilai sosio-kultural pada siswa SMA di Minahasa. Mimbar, 31(2), 319327

[2] Pangalila, T. (2017). Peningkatan civic disposition siswa melalaui Pendidikan Kewarganegaraan (PKn), 7(1)

[3] Burroughs, S., Hopper, P. F., Brocato, K., \& Sanders, A. (2007). Teaching for and about Citizenship in a Democratic Society: Comparative Views of a Selected Civic Educators in the United States, Europe, and Latin America. International Journal of Social Education, 22(2), 49-69.

[4] Owen, D. (2015). High School Student's Acqusition of Civic Dispositions: The Impact of We the People.

[5] Porfilio, B. J., \& Gorlewski, J. A. (2012). Promoting Active Citizenship through the arts and youth: Canadian Youth-Led Organizations as Beacons of Hope and Transformation. International Journal of Progressive Education, 8(2).

[6] Pasandaran, S. (2013). Editor: In F. Kerebungu, S. B. Kairupan, A. L. Lonto, \& T. Pangalila (Eds.), Pengembangan Pendidikan Karakter Dalam Persektif Kurikulum 2013 (pp. 1-20). Manado: Fakultas Ilmu Sosial Unima.

[7] Branson, M. S. (1998). The role of civic education: A forthcoming Education Policy Task Force position paper from the Communitarian Network. Center for Civic Education.

[8] Budimansyah, D., \& Suryadi, K. (2008). PKn dan masyarakat multikultural. Bandung: Program Studi Pendidikan Kewarganegaraan UPI.

[9] Lumpkin, A. (2008). Teachers as role models teaching character and moral virtues. Journal of Physical Education, Recreation \& Dance, $79(2), 45-50$.

[10] Lunenberg, M., Korthagen, F., \& Swennen, A. (2007). The teacher educator as a role model. Teaching and Teacher Education, 23(5), 586601 .

[11] Nassozi, I. (2010). The effect of teachers' leadership role on students' discipline in secondary schools in Wakiso District. Makerere University.

[12] Ribeiro, A. B., Rodrigues, M., Caetano, A., Pais, S., \& Menezes, I. (2012). Promoting" Active Citizens"? The Critical Vision of NGOs over Citizenship Education as an Educational Priority across Europe. International Journal of Progressive Education, 8(3). 